\title{
Structural Co-Alignment Influence on SMEs Performance
}

\author{
Diego Armando Marín-Idárraga ${ }^{1} \&$ Juan Carlos Cuartas-Marín ${ }^{2}$ \\ ${ }^{1}$ Program of Business Management, Jorge Tadeo Lozano University, Colombia \\ ${ }^{2}$ Program of Business Management, Autónoma of Colombia University, Colombia \\ Correspondence: Diego Armando Marín-Idárraga, Program of Business Management, Jorge Tadeo Lozano \\ University, Cra. 4 No. 22.61, M1 of. 329, Bogotá, Colombia. Tel: 57-1-695-2769. \\ E-mail:diego.marin@utadeo.edu.co
}

Received: September 16, 2013

Accepted: October 10, 2013

Online Published: October 15, 2013

doi:10.5539/ijbm.v8n22p76

URL: http://dx.doi.org/10.5539/ijbm.v8n22p76

\begin{abstract}
Organizational structure is a determining factor in organizational performance. Although structural contingency theory in the field of organizational studies and the structural co-alignment theory in the field of strategic management, have provided points of reference to comprehend the phenomenon of organizational performance, there are still gaps to be filled and empirical validation is required, above all in the influences on performance and especially in relation to Colombian Small and Medium Enterprises (SMEs). As such, the objective of this study is to determine the effect of structural co-alignment on organizational performance, applying causal inference methodology to a structural equations model. The results will indicate that differentiation, centralization and formalization have a synergistic effect on performance, when the fit is achieved.
\end{abstract}

Keywords: organizational structure, structural co-alignment, organizational performance

\section{Introduction}

It's well known that the phenomenon of economic globalization imposes immeasurable challenges for organizations. Governmental strategies to position to Colombia in the international market, above all the recent FTA with the United States generate a paradoxical commercial environment of opportunities and threats, whence national companies must develop competitive capabilities. Porter's (1990) maxim, (the competitiveness of a country, is the result of the competitiveness of its industries and sectors), recognizes the need for companies to develop key competencies which guarantee their durability and competitive success (Hamel \& Prahalad, 1990; Tidd, 2000).

This is precisely what authors such as Wernerfelt (1984), Barney (1991) and Grant (1991) have proposed in their efforts to explain how the management of internal resources is a determinant of competitive advantages. Among these, the definition of an organizational structure, which is in accordance with the environment and organizational performance objectives, is a necessary condition for competitiveness (Nadler \& Tushman, 1999).

However, the current situation of Colombian Small and Medium Enterprises (SMEs) in terms of organizational design, illustrates a less-than-encouraging reality. A recently released study on a sample of industrial SMEs in Bogotá (Marín-Idárraga, 2012), found a degree of informality when it comes to implementing actions aimed at organizational restructuring, due in many cases, to the lack of knowledge regarding the variables of organizational structuring. The results evidenced, in terms of organizational structuring, that SMEs in Bogotá demonstrate an unbalanced structure, which is incongruent with the situational factors of their environment and strategy.

Therefore, given the argument that organizational structure is an endogenous factor which induces performance, and which is essential to the competitive ability of companies, there is an urgent need for consolidation and development among Colombian SMEs, especially, as this group of organizations, represents close to $10 \%$ of companies ( $81 \%$ are micro enterprises), generating $46 \%$ of industrial employment and more than $50 \%$ of jobs in the commercial sector, as well as providing more than $35 \%$ of national industrial production (Rodríguez, 2003).

As such, the starting point should be the analysis of structural fit, for which the following research question is posed: how does structural co-alignment influence on the performance of industrial SMEs in Bogotá?

The theoretical framework was empirically verified using a structural equations model on a sample of industrial 
SMEs in the city of Bogotá, whose results demonstrate that structural co-alignment has a greater influence on performance than the isolated analysis of each separate variable (Venkatraman, 1989; 1990), which represents an important theoretical contribution to organizational theory and the management of SMEs. This, therefore, is the argument that supports the relevance of this article, which is divided into five parts. In the first part, the theoretical framework is set out; in the second part, the methodology is presented; in the third part, the results are provided; in the fourth part, a discussion of the findings is carried out; in the final part, the conclusions are presented, as well as limitations and future lines of investigation.

\section{Theoretical Framework}

\subsection{Structural Contingency Theory}

The conceptualization of the organization as a system, which receives influences from the environment, led various theorists to become interested in analyzing the effect of such incidents on organizational performance, whose investigations gave rise to contingency theory. As Kast \& Rosenzweig (1972) explain, systems theory laid the foundations for subsequent considerations of organizational contingencies by establishing the existence of a sub-environment to which organizations belong.

Ergo, a naturalist, systemic and situational way of comprehending organizations, replaced the classical perspective of organizations as mechanistic and shielded entities. Along these lines of thinking, contingency theory establishes that in response to environmental conditions, organizations design different ways of functioning during their existence due to the impact that they receive from different situational factors (Galbraith, 1973). This implies that in the face of different environmental conditions, different types of structural fit will be required (Burns \& Stalker, 1961; Child, 1972; Lawrence \& Lorsh, 1967).

According to Donaldson (2001), contingency factors are influenced by these contextual conditions such as strategy, size, technology and task uncertainty, which impact on the organizational design. As these contextual conditionshave an effect on organizational structure variables, this research focus has been named structural contingency theory.

The fundamental premise of structural contingency theory is that the environment and other situational factors impact on the organization and the organization seeks to adjust its endogenous variables by continuously experimenting with different ways of structuring (Donaldson, 2001). Taylor's approach regarding a better way to administrate (the best way), or Williamson's (1970) proposal regarding the M-form as the ideal structural configuration give way to the contingency theory maxim that "there is no one best way to organize; any way of organizing is not equally effective" (Galbraith, 1973, p. 2) (Note 1).

\subsection{Structural Co-Alignment Theory}

Traditional organizational theory, proposed causal associations, between the variables that affect organizations: the influence of $X$ always produces the effect $Y$ (e.g., functional theories and behavioral theories of needs). According to contingency theory, the variables influence each other in a situational way, and a change between two variables will affect third-party variables (Dewar \&Werbel, 1979; Schoonhoven, 1981; Venkatraman, 1989). It is precisely the notion of contingency, which suggests that it is impossible to find one best way of structuring an organization, given that performance will be influenced by changing circumstances between endogenous variables and external factors (Donaldson, 2001; Veliyath \& Srinivasan, 1995). According to Sillince (2005), this is the basis from which structural co-alignment theory - also known as fit theory or organizational congruence theory-emerges, considering that: i) there is an association between contingent factors and the structure of an organization, ii) these contingent factors influence the structure of an organization, and iii) organizational structure seeks to adapt itself to contingent factors in order to achieve high levels of performance above all, in terms of congruence between environment, strategy and structure.

Under this framework, organizational congruence theory (or structural co-alignment) transcends structural contingency theory by indicating that performance is not merely included in the organizational design of structural variables induced by the environment, but that these variables must also be the object of strategic adjustments in order to drive improvements in performance (Ensign, 2001).

The origins of this theory go back to the initial works of Drazin\& Van de Ven (1985), Donaldson (1987) and Fry \& Smith (1987) on organizational environment, and to Venkatraman\& Camillus (1984) and Venkatraman (1989) in the field of strategic management. The common characteristic between these different approximations is the necessity of a congruent state, known as fit, which has been accepted as a linguistic symbol to explain the synchrony, consistency or coherence required between situational factors, endogenous structural parameters and organizational development in a holistic and integrated way; authors such as Nadler \& Tushman (1999) have 
chosen to call this congruence.

\section{Formulation of Hypotheses}

Figure 1 shows the referential diagram that will guide the formulation of the research hypotheses:

The influence of organizational structure on performance has been extensively investigated, however the results are still not conclusive due to various contradictions, as in some cases positive relationships are found between the variables and in other cases negative relationships are found (Dalton, Todor, Spendolini, Fielding, \& Porter, 1980). The pioneering study of Hage (1965) found an inverse relationship between differentiation and performance, while Santra \& Giri's (2008) study found positive effects between formalization, centralization and organization effectiveness. Kimberly \& Rottman (1987) and Meijaard, Brand \& Mosselman (2005) indicated a positive impact of organizational structure on the organizational performance, and, for their part, Sarkees, Hulland \& Prescott (2010) discovered that functional differentiation exercises a moderating effect on the relationship between innovation and performance.

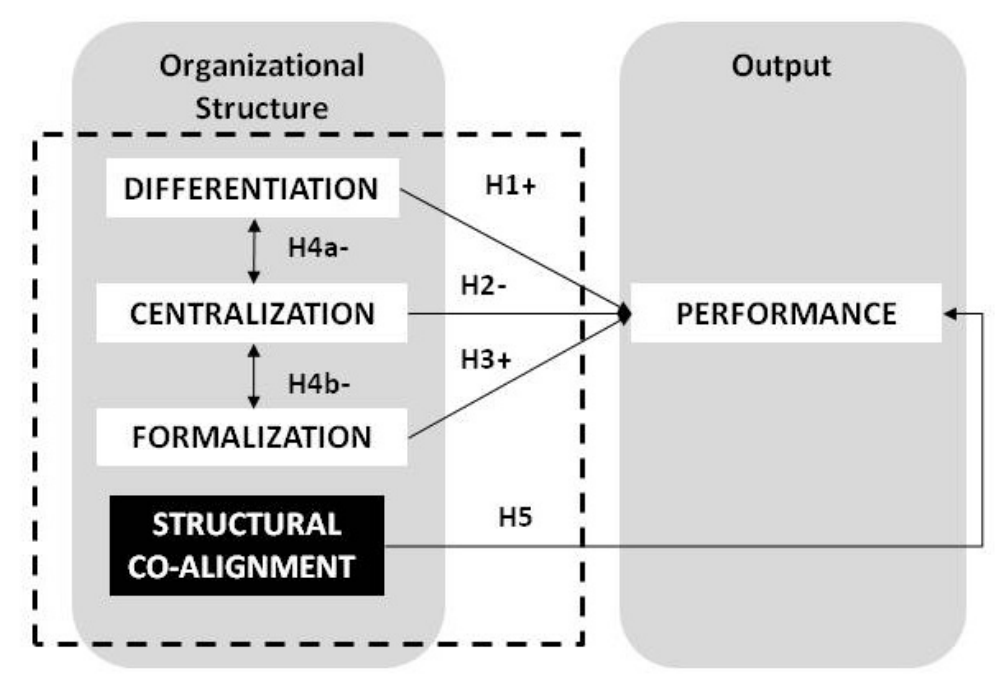

Figure 1. Conceptual model and hypotheses

It is considered that among SMEs in Bogotá's manufacturing sector, given their restrictions in terms of size: i) greater functional division would lead to a higher level of organizational performance, as this would allow the existence of specific responsibility centers which are responsible for attending to particular problems, ii) the centralization of decision making will involve slow and inflexible processes, known that this produces mechanical structures (Mintzberg, 1979), and iii) the normalization of processes is a response by organizations faced with the need to increase control (Child, 1973; Clegg, 1981). Therefore, the following hypotheses are posed:

H1: Differentiation has a positive and significant influence on performance.

H2: Centralization has a negative and significant influence on performance.

H3: Formalization has a positive and significant influence on performance.

H4a: Centralization is negatively and significantly correlated with differentiation.

H4b: Centralization is negatively and significantly correlated with formalization.

As has already been explained previously, structural co-alignment theory (Donaldson, 1987; Drazin \& Van de Ven, 1985; Ensign, 2001; Venkatraman \& Camillus, 1984; Venkatraman, 1990) proposes that congruence between endogenous structural factors comprises a significant determinant of superior organizational performance. Given the lack of prior studies which co-align structural differentiation, centralization and formalization variables to evaluate their joint impact on performance, it is hypothesized here that when these variables fit, they exercise a synergic effect on the organizational results of SMEs in Bogota which is much greater than if they are considered separately. Therefore, the following hypotheses are formulated:

H5a: Differentiation has a greater positive effect on performance under conditions of structural co-alignment with centralization and formalization.

H5b: Centralization has a greater negative effect on performance under conditions of structural co-alignment 
with differentiation and formalization.

H5c: Formalization has a greater positive effect on performance under conditions of structural co-alignment with differentiation and centralization.

H5d: Co-alignment between structural factors has a positive and significant influence on organizational performance.

\section{Methodology}

\subsection{Sample and Data}

The investigation was carried out through an explicative and cross sectional study. The unit of analysis considered was the company and methodological issues in similar studies were taken into account (e.g., Lee \& Grover, 1999; Liao, Chuang \& To, 2011). Table 1 describes the characteristics of the target population.

Table 1. Technical specifications for the study

\begin{tabular}{ll}
\hline Scope: & Bogotá D.C. \\
\hline Time: & 12 months. \\
Universe: & Industrial SMEs in Bogotá. \\
Sampling units: & CIIU Rev. 3.1 A.C. to 2 digits. \\
Sampling frame: & BPR Benchmark Database ${ }^{\mathrm{TM}}$. \\
Respondents: & Strategic Apex directors and mid-level managers (Mintzberg, 1979). \\
\hline
\end{tabular}

To obtain the sample, the probability method of simple random sampling was used, applying the formula for finite populations (Malhotra, 1999). The Benchmark database was used as a sampling framework. Following the indications of Babbie (2010) and Malhotra (1999), the companies considered for the study was limited to those located in Bogotá, belonging to the manufacturing sector, within the SME range in terms of number of employees, those currently in operation, and those with contact details and emails available to be able to send the questionnaire. The results provided a total of 1,561 productive units that could be evaluated, to which the sampling formula for finite populations was applied with an estimation error of $5 \%$. Once the sampling calculations were applied, the final sample was 309 companies to give a confidence level of $95 \%$.

Data collection was conducted with a self-administered survey based on a structured questionnaire directed to strategic directors and mid-level managers of the companies. According to Mintzberg (1979), these are the employees responsible for the direction and implementation of organizational strategy when it comes to participating in decision-making processes.

Once the field work was concluded, 163 completed questionnaires were obtained, of which 12 were eliminated because they included unanswered questions, giving a final sample of 152 valid cases which represents a reply rate of $49.2 \%(152 / 309)$, which is considered acceptable for this type of research (Baruch, 1999) and is greater than many similar investigations. (e.g., Lee \& Yang, 2011; Liao et al., 2011; Menguc \& Auh, 2010).

A total of $53.3 \%$ (87) of the respondents were mid-level managers and $46.7 \%$ (71) were strategic directors. To establish whether differences between the responses obtained from these two organizational levels exist, the Mann-Whitney U Test was applied, obtaining in every case, a statistical significance of ( $p>.05)$, which indicates that there are no differences between the responses given by strategic directors and those given by mid-level managers.

In virtue of the fact that responses were not obtained from the entire initial sample (309 companies), the possible existence of a non-response bias was tested using data known about the whole population, such as company size and annual sales volume (Armstrong \& Overton, 1977). The analysis using a Student's t-test indicated that there are no significant differences between companies that responded to the survey and those that did not respond $(p>.05)$.

\subsection{Variables and Measurement}

A structured questionnaire was created based on the reviewed bibliography of previous research. All of the items were quantified using a seven-point Likert scale, with one being the lowest level and seven the highest level to evaluate the existence of a given phenomenon in the company. 


\subsubsection{Organizational Structure}

Organizational structure comprised the independent variable of the study, defined as the collection of ways in which work can be divided and subsequently integrated or coordinated in an organization (Hage \& Aiken, 1967; Mintzberg, 1979; Pugh, Hickson, Hinnings, \& Turner, 1968). Organizational structure is usually been measured in terms of the variables that it is composed (Liao et al., 2011; Menguc \& Auh, 2010), based on different configurations of variables in line with the initial studies of de Pugh et al. (1968) and Hage (1965). These commonly accepted variables include differentiation, formalization and centralization as the principal determinants of organizational structure (Dalton et al., 1980; Damanpour \& Gopalakrishnan, 1998; Lee \& Grover, 1999).

The division of labor in an organization occurs horizontally, and is understood as the creation of areas of functional responsibility (Kilduff, 1993), and also vertically, based on the establishment of control levels that originate form a hierarchical chain (Damanpour \& Gopalakrishnan, 1998). Differentiation is associated with greater or lesser organizational complexity and has a direct relationship with the size of the organization (Anderson \& Warkov; 1961; Blau, 1970). This study measured vertical differentiation with three items identified by Lee \& Yang (2011) \& Lenz (1980).

Formalization is understood as a control mechanism for organizational work (Clegg, 1981) through the definition of labor standards and protocols, which are generally documented, in order to guide employee behavior (Caruana, Morris, \& Vella, 1998; Mintzberg, 1979). The measurement of this variable follows the common pattern of the pioneering works of Hage (1965) and Pugh, et al. (1968).

Centralization corresponds to a locus of decision-making rights in an organization (Caruana, et al., 1998; Fredrickson, 1986; Hage \& Aiken 1967), which are generally concentrated at the strategic-level (Mintzberg, 1979). The delegation of decision making to other levels of the organization corresponds to decentralization. In this study decentralization was measured with three items adapted from Lee \& Yang (2011), which were subsequently reversed to reflect the amount of centralization in the company.

\subsubsection{Organizational Performance}

Organizational performance comprised the dependent variable of the study. It is defined as the extent to which an organization achieves its objectives of efficiency and effectiveness (Neely, Gregory \& Platts, 1995) and therefore corresponds to a valuation of productivity. This has been an important factor in the evolution of strategic management (March \& Sutton, 1997; Rumelt, Schendel \& Teece, 1991), but despite the different approximations developed to measure it, organizational performance continues to be a subject of investigation due to its complex and unobservable character (Slater \& Olsen, 2000; Venkatraman \& Ramanujam, 1986), thathas lead to multiple discrepancies in its definition and operationalization (Nudurupati, Bititci, Kumar, \& Chan, 2011).

In general, the measurement of performance has been subject to one-dimensional and multidimensional measures. The former correspond to financial or economic indicators, while the latter correspond to non-financial indicators of operations (Venkatraman \& Ramanujam, 1986). Other contemporary perspectives have considered performance as an integrated and holistic reporting construct, e.g. the Balanced Scorecard (Kaplan \& Norton, 1992).

Operationalizing the measurement of performance has been conducted based on objective scales (financial and operational) and subjective scales based on self-perception (Venkatraman \& Ramanujam, 1986). Authors such as Atuahene-Gima (2005), Li, Chu, \& Lin (2010) and Zhang, Linderman, \& Schroeder (2012) have shown the benefits of subjective performance measurement; this type of measurement is utilized in this study with 4 items adapted from Lee and Yang (2011).

\subsubsection{Structural Co-Alignment}

Venkatraman (1990) defines co-alignment as a metaphor to represent the fit between different theoretical dimensions. However, he believes that this idea is difficult to measure given the complexity of the constructs that aims to test empirically. Venkatraman proposes three methodological alternatives: i) interactionism approach, based on a moderation analysis between the variables, ii) profile deviation approach, which evaluates the congruence between the variables depending on their adherence to a profile specified a priori and externally by the investigator, and iii) the co-variation approach, which evaluates the internal consistency of the variables using a structural model.

Given that this investigation uses a structural equations model (Bentler \& Weeks, 1980; Byrne, 2006), the 
co-variation perspective was adopted to measure structural co-alignment.

\subsection{Validity of Scales}

In virtue of the fact that the scales used in this research corresponded to adaptations from previous studies, the methodological literature recommends carrying out the corresponding tests of validity (Babbie, 2010; Malhotra, 1999).

\subsubsection{Content Validity}

According to Hair, Black, Babin, \& Anderson (2009), content validity is an evaluation of the level of correspondence between the articles selected to constitute an additive scale and its conceptual definition. To achieve this, a pretest was conducted in which the four expert academic judges evaluated the questionnaire. To determine the validity of each item and their viability in the scale, the content validity index is obtained $\left(I_{V C}\right)$ using the following formula.

$$
I_{V C}=\frac{\sum_{i=1}^{n}\left(R_{i}+p_{i}+E_{i}+L_{i}\right)}{16 n}
$$

Where:

$R_{i}=$ Score assigned to the Composition category by judge $i$.

$P_{i}=$ Score assigned to the Relevance category by judge $i$.

$E_{i}=$ Score assigned to the Structure by judge $i$.

$L_{i}=$ Score assigned to the Language by judge $i$.

$\mathrm{n}=$ Number of judges.

Values above 0.7 guarantees that the indicator is good, and indicates that the item is appropriate for the scale, that determines its validity. In the case of this study, all of the questions obtained a score of above 0.7 , and as such it is concluded that the scales possess content validity and no modifications are necessary. Furthermore, a pilot test was applied to three companies chosen in the sample without any critical issues detected in their completion of the questionnaire.

\subsubsection{One-Dimensional Contrast}

The one-dimensionalcontrast seeks to determine "if every collection of alternative indicators has a common underlying characteristic or construct" (Anderson \& Gerbing, 1988). The contrast is conducted using an exploratory factor analysis with Varimax rotation, employing the criteria of self-values greater than 1 and verifying its viability through KMO and Barlett tests (Hair et al., 2009). All of the scales presented factorial loads of greater than 0.6 , indicating their statistical significance, and as such verifying the one-dimensionalstructure. The results are presented in Table 2.

Table 2. One-dimensional analysis

\begin{tabular}{ccccc}
\hline Variables & \multicolumn{3}{c}{ Factor } \\
& 1 & 2 & 3 & 4 \\
\hline Perform_V10 & 0.865 & & & \\
Perform_V11 & 0.841 & & & \\
Perform_V12 & 0.822 & & & \\
Difer_V1 & & 0.832 & & \\
Difer_V2 & & 0.813 & & \\
Difer_V3 & & 0.810 & & 0.757 \\
Formal_V7 & & 0.835 & 0.751 \\
Formal_V8 & & & 0.751 & 0.723 \\
Formal_V9 & & & & \\
Central_V4 & & & & \\
Central_V5 & & & & \\
Central_V6 & & & & \\
\hline
\end{tabular}

$\mathrm{KMO}=0.81$; Bartlett's sphericity $X_{(171)}^{2}=672.004 ; p<.05$; Total variance explained $=71,02$. 


\subsubsection{Internal Consistency}

Internal consistency establishes the reliability of a scale, controlling for errors caused by people who respond to the survey, as it verifies that the scales are measuring the same construct. It is obtained using Cronbach's Alpha in the exploratory factor analysis (Nunnally, 1978), Bagozzi and Yi's (1988) scale composite reliability (SCR) and the Average Variance Extracted (AVE) (Fornell \& Larker, 1981) in the confirmatory factor analysis. According to Hair et al. (2009), the general consensus on the lower limit of Cronbach's Alpha and the SCR is 0.70 , although it could decrease to 0.60 in the exploratory investigation; for the $A V E$ the lower limit is 0.5 . Cronbach's Alpha was obtained using the software PASW Statistic and the SCR and AVE indicators were calculated with data obtained using the software EQS 6.1 (Bentler, 2006), as well as with the application of the following formulas:

$$
S C R=\frac{\sum\left(\lambda_{i}\right)^{2} \operatorname{var}(\xi)}{\sum\left(\lambda_{i}\right)^{2} \operatorname{var}(\xi)+\sum \theta_{i i}}
$$

Note: Bagozzi \& Yi, 1988.

$$
A V E=\frac{\sum \lambda_{i}^{2} \operatorname{var}(\xi)}{\sum\left(\lambda_{i}\right)^{2} \operatorname{var}(\xi)+\sum \theta_{i i}}
$$

Note: Fornell \& Larcker, 1981.

Where:

$\sum\left(\lambda_{\mathrm{i}}\right)^{2} \operatorname{var}(\xi)=$ The sum of standard weightings squared.

$\sum \lambda_{i}{ }^{2} \operatorname{var}(\xi)=$ The sum of squares of the standard weightings.

$\sum \theta_{i i}=$ The sum of measurement error of the indicator *

* Measurement error was calculated as $1-\lambda^{2}$.

The results are presented in Table 3, in which it can be seen that: For differentiation $\alpha=0.82, S C R=0.82, A V E$ $=0.60$; for centralization $\alpha=0.69, S C R=0.71, A V E=0.45$; for formalization $\alpha=0.78, S C R=0.78, A V E=0.54$; and for performance $\alpha=0.83, S C R=0.83, A V E=0.62$. With the exception of $\alpha$ and $A V E$ for centralization, all of the other dimensions have values of $\alpha$ and $S C R$ above 0.7 and values of $A V E$ above 0.5 . The decision was taken to maintain the centralization factor, given that the values are very close to the acceptable lower limit, and according to the assessment of Chin (1998), the rules of Structural Equation Modeling (SEM) should not be too inflexible when there are no significant deviations. Therefore, the internal consistency of the scales is confirmed.

\subsubsection{Convergent Validity}

Convergent validity estimates the extent to which attempts to measure the same concept is concordant with each other (Hair et al, 2009). To establish convergent validity, a confirmatory factor analysis was conducted applying the maximum likelihood procedure based on the covariance matrix, using the software EQS 6.1 (Bentler, 2006). Higher levels of convergence between one-dimensional factors will provide higher scores, with values of above 0.5 acceptable (Anderson \& Gerbing, 1988; Fornell \& Larcker, 1981).

To evaluate the goodness of the fit, different indicators suggested by the literature were used (Byrne, 2006; Hair et al., 2009). As such, various indicators were calculated, including: i) the Chi squared test based on the maximum likelihood procedure, where $X^{2} / d f \geq 2$ is considered acceptable (Bagozzi \& Yi, 1988), ii) the relative fit indices, which can be used to compare the result of the model against another model with a less good fit, values above 0.9 are acceptable (Bagozzi \& Yi, 1988; Hooper, Coughlan, \& Mullen, 2008). In this case the Comparative Fit Index (CFI), the Non-Normed Fit Index (NNFI) and the Incremental Fit Index (IFI) were used. And iii) the Root Mean Square Error of Approximation (RMSEA), evaluates how close the fit is to the null hypothesis, where values lower than 0.08 are acceptable (Hooper et al., 2008).

The results registered in Table 3 show that, although the Chi squared $X_{(49)}^{2}=93.61, p<.05$, did not provide a significant result, which is common when samples of more than 150 units are processed (Martínez-López, Gázquez-Abad, \& Sousa, 2013), the maximum likelihood method indicators CFI $=0.95$, IFI $=0.95$, NNFI $=$ 0.93 , RMSEA $=0.07$, show that the model has an acceptable fit (Bagozzi \& Yi, 1988; Hooper et al., 2008). The standardized solution gave scores greater than 0.5 in all of the dimensions, and the maximum likelihood values $(t)$ were statistically significant $(p<.05)$, which verifies convergent validity. 
Table 3. Evaluation of the measurement model

\begin{tabular}{|c|c|c|c|}
\hline & Standard loading & $\begin{array}{c}\text { Statistic } \\
\text { t-value }\end{array}$ & Reliability \\
\hline & & & $\alpha=0.82$ \\
\hline \multirow[t]{2}{*}{ Differentiation } & & & $S C R=0.82$ \\
\hline & & & $A V E=0.60$ \\
\hline $\mathrm{V} 1$ & 0.78 & $-^{\mathrm{a}}$ & \\
\hline V2 & 0.74 & $8.30^{*}$ & \\
\hline \multirow[t]{2}{*}{ V3 } & 0.82 & $8.61^{*}$ & \\
\hline & & & $\alpha=0.69$ \\
\hline \multirow[t]{2}{*}{ Centralization } & & & $S C R=0.68$ \\
\hline & & & $A V E=0.43$ \\
\hline V4 & 0.47 & ${ }^{\mathrm{a}}$ & \\
\hline V5 & 0.74 & $4.65^{*}$ & \\
\hline \multirow[t]{2}{*}{ V6 } & 0.71 & $4.64^{*}$ & \\
\hline & & & $\alpha=0.78$ \\
\hline \multirow[t]{2}{*}{ Formalization } & & & $S C R=0.78$ \\
\hline & & & $A V E=0.54$ \\
\hline V7 & 0.68 & $-{ }^{\mathrm{a}}$ & \\
\hline V8 & 0.81 & $7.32 *$ & \\
\hline \multirow[t]{2}{*}{ V9 } & 0.72 & $7.05^{*}$ & \\
\hline & & & $\alpha=0.83$ \\
\hline \multirow[t]{2}{*}{ Performance } & & & $S C R=0.83$ \\
\hline & & & $A V E=0.61$ \\
\hline $\mathrm{V} 10$ & 0.76 & $-{ }^{\mathrm{a}}$ & \\
\hline V11 & 0.80 & $8.60^{*}$ & \\
\hline $\mathrm{V} 12$ & 0.79 & $8.58^{*}$ & \\
\hline
\end{tabular}

$-{ }^{\mathrm{a}}$ Fixed parameters; $* p<.05 ; X^{2}{ }_{(49)}=83.61, p<.05 ; \mathrm{CFI}=0.95 ; \mathrm{IFI}=0.95 ; \mathrm{NNFI}=0.93 ; \mathrm{RMSEA}=0.07$.

\subsubsection{Discriminant Validity}

Discriminant validity indicates whether each factor corresponds to a different dimension, as it represents the degree to which theoretically similar concepts differ from each other (Hair et al., 2009). Discriminant validity is said to occur when the Average Variance Extracted $(A V E)$ is greater than the correlation between the constructs squared (Anderson \& Gerbing, 1988).

In Table 4 the inter-correlations and square root of $A V E$ are provided in the main diagonal, verifying that in each case the square root of $A V E$ is greater than the inter-correlations, thus confirming discriminant validity. (Note 2)

Table 4. Means, standard deviations and correlations

\begin{tabular}{|c|c|c|c|c|c|c|}
\hline & M & SD. & 1 & 2 & 3 & 4 \\
\hline 1. Differentiation & 3.87 & 1.33 & 0.77 & & & \\
\hline 2. Centralization & 3.96 & 1.18 & $-0.42 *$ & 0.66 & & \\
\hline 3. Formalization & 4.86 & 1.33 & $0.44^{*}$ & $-0.44^{*}$ & 0.73 & \\
\hline 4. Performance & 4.96 & 1.06 & $0.23 *$ & $-0.24 *$ & $-0.39 *$ & 0.78 \\
\hline
\end{tabular}

$\mathrm{N}=152 ; * p<.01$. The values of the main diagonal (in italics) correspond to the square root of AVE.

\section{Results}

This investigation developed a structural equations model to verify the hypothesis (Bentler \& Weeks, 1980; Jöreskog, 1978). Structural equations modeling, as it is known in the investigative field, is a type of multivariate technique thatpermits the simultaneous examination of a series of dependent relationships, in which a dependent variable can at the same time be an independent in subsequent relationships. 
According to Anderson \& Gerbing (1988), the process was conducted in two phases; in the first phase the measurement model was obtained, that also served to perform a confirmatory factor analysis on the scales used, and in the second phase, the first order structural model was obtained, andwas used to confirm the hypothesis. Firstly, it was verified that both the measurement model and the structural model were over-identified to guarantee that there was more information in the data matrix than parameters to be estimated (Byrne, 2006; Hair et al., 2009). Both the measurement and the structural model obtained positive values in degrees of freedom, determining the existence of over-identification. The process was conducted on the softwareEQS 6.1, a program specialized in structural equations (Bentler, 2006).

\subsection{Structural Model and Confirmation of the Hypothesis}

Thestructural model is evaluated by examining the dependence coefficients of the variables and of the latent factors. Figure 2 illustrates the corresponding relationships in the initial structural model.

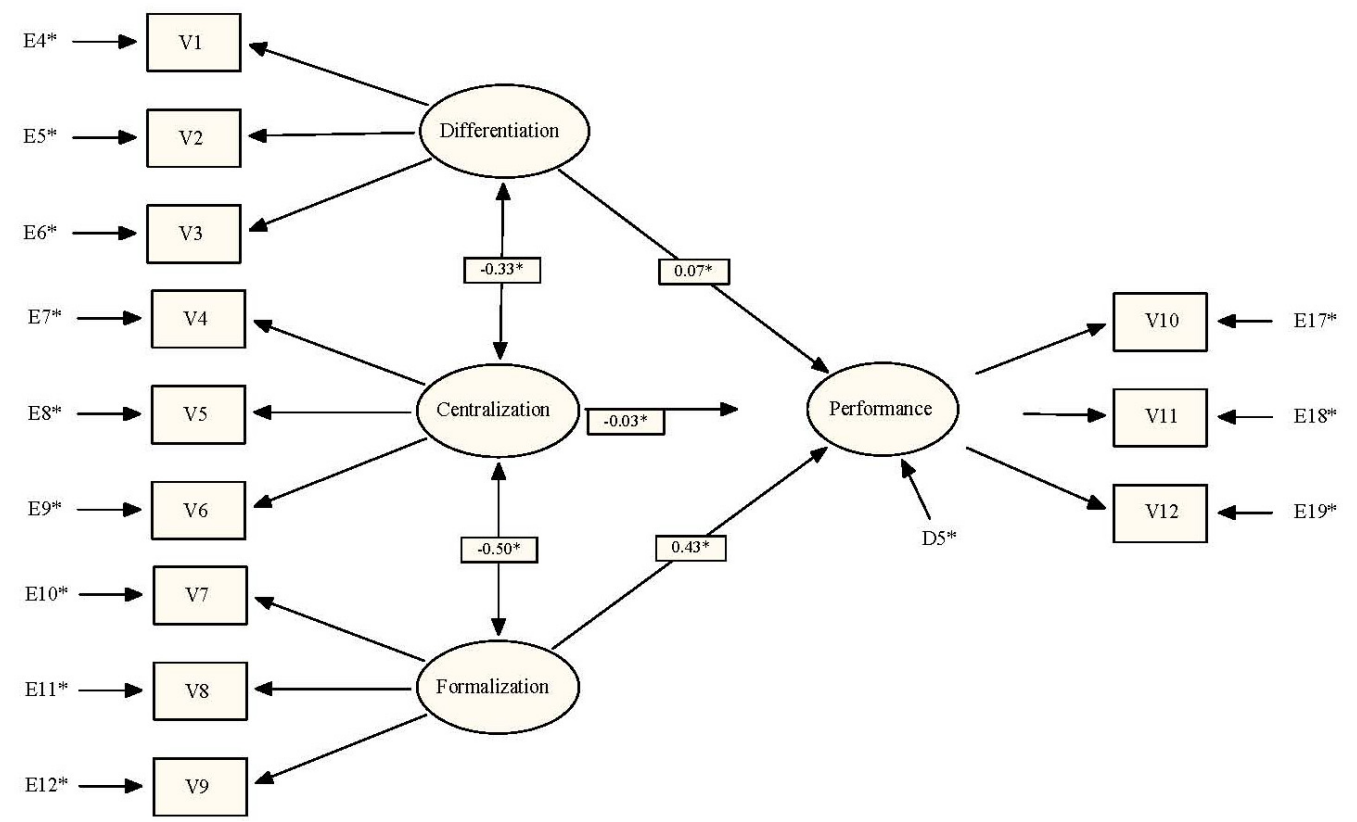

Figure 2. Initial structural model

The model was initially run to evaluate the hypothesis regarding the influences of organizational structure on performance, obtaining an acceptable fit $\left(X^{2}{ }_{(49)}=83.61, p<.05\right.$; CFI $=0.95$; IFI $=0.95$; NNFI $=0.93$; RMSEA $=0.07$ ), whose results are in line with similar studies (Liao et al., 2011; Zheng, Yang, \& McLean, 2010).In Table 5 it can be seen that a) differentiation has no influence on performance $(0.07 ; t=0.69, p>.05)$, and as such hypothesis 1 is not supported; b) centralization has no influence on performance $(-0.03 ; t=-0.24, p>.05)$, and as such hypothesis 2 is not supported;c)formalization has a positive and significant influence on performance $(0.43 ; t=3.20, p<.05)$, which verifies hypothesis $3 ; \mathrm{d})$ centralization has a negative and significant influence on differentiation $(-0.33 ; t=-2.76, p<.05)$ which supports hypothesis $4 \mathrm{a}$; and e) centralization has a negative and significant influence on formalization $(-0.50 ; t=-3.33, p<.05)$ which supports hypothesis $4 \mathrm{~b}$. 
Table 5. First order structural model

\begin{tabular}{cccccc}
\hline & Path & Standard loading & t value & Hypothesis & Supported \\
\hline a & Differentiation $\rightarrow$ Performance & 0.07 & 0.69 & $H 1$ & No \\
b & Centralization $\rightarrow$ Performance & -0.03 & -0.24 & $H 2$ & No \\
c & Formalization $\rightarrow$ Performance & 0.43 & $3.20^{*}$ & $H 3$ & Yes \\
d & Formalization $\rightarrow$ Differentiation & $-0.33^{*}$ & $-2.76^{*}$ & $H 4 a$ & Yes \\
e & Centralization $\rightarrow$ Formalization & $-0.50^{*}$ & $-3.33^{*}$ & $H 4 b$ & $\mathrm{Si}$ \\
\hline
\end{tabular}

$* p<.05 ; X_{(49)}^{2}=83.61, p<.05 ; \mathrm{CFI}=0.95 ; \mathrm{IFI}=0.95 ; \mathrm{NNFI}=0.93 ; \mathrm{RMSEA}=0.07$.

The structural model was then run under co-variation conditions (Venkatraman, 1990), with the relationships between factors shown in figure 3 .

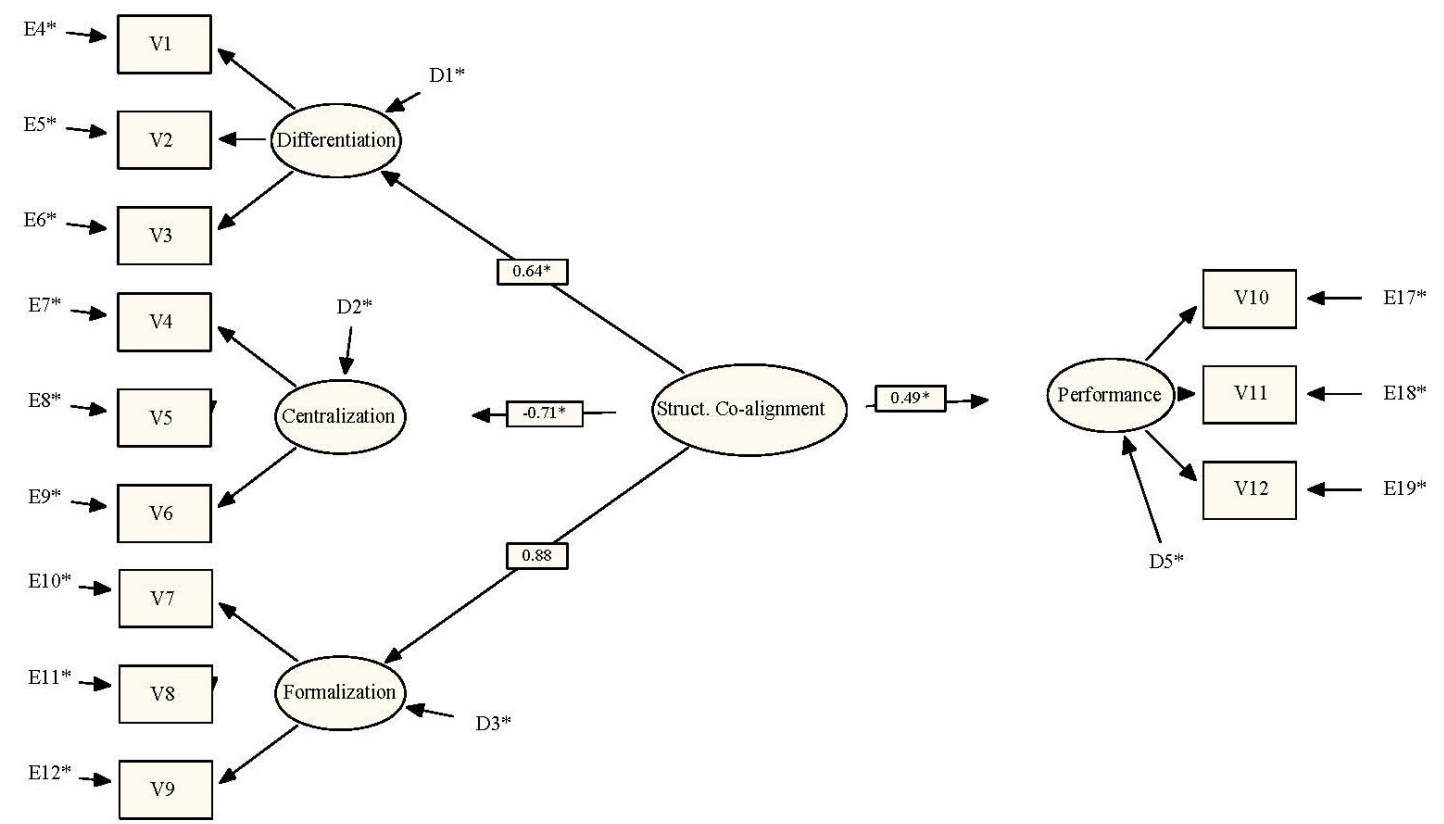

Figure 3. Structural co-alignment model

Firstly, the goodness of fit of the co-aligned model is greater than in the initial model $\left(X^{2}{ }_{(50)}=52.05, p>.05\right.$; CFI $=0.99 ; \mathrm{IFI}=0.99$; NNFI $=0.99 ;$ RMSEA $=0.02$ ). The results presented in Table 6 indicates that: $\mathrm{f}$ ) differentiation has a greater positive effect on performance under conditions of structural co-alignment with centralization and formalization $(0.64 ; \mathrm{t}=4.51, \mathrm{p}<.05)$, which supports the hypothesis $5 \mathrm{a} ; \mathrm{g})$ centralization has a greater negative effect on performance under conditions of structural co-alignment with differentiation and formation $(-0.71 ; \mathrm{t}=-3.77, \mathrm{p}<.05)$, supporting hypothesis $5 \mathrm{~b} ; \mathrm{h})$ formalization has a greater positive effect on performance under conditions of structural co-alignment with differentiation and centralization (0.88), supporting hypothesis $5 \mathrm{c}$; i) structural co-alignment has a positive and significant influence on organizational performance $(0.49 ; \mathrm{t}=3.91, \mathrm{p}<.05)$, supporting the hypothesis $5 \mathrm{~d}$. 
Table3. Structural model in co-alignment (covariance)

\begin{tabular}{cccccc}
\hline & Path & Standard loading & t value & Hypothesis & Supported \\
\hline $\mathrm{f}$ & Differentiation $\rightarrow$ Structural co-alignment & $0.64^{*}$ & 4.51 & $H 5 a$ & Yes \\
$\mathrm{g}$ & Centralization $\rightarrow$ Structural co-alignment & $-0.71^{*}$ & -3.77 & $H 5 b$ & Yes \\
$\mathrm{h}$ & Formalization $\rightarrow$ Structural co-alignment & $0.88^{*}$ & $-^{\mathrm{a}}$ & $H 5 c$ & Yes \\
$\mathrm{i}$ & Structural co-alignment $\rightarrow$ Performance & $0.49^{*}$ & $3.91^{*}$ & $H 5 d$ & Yes \\
\hline
\end{tabular}

$\mathrm{-}^{\mathrm{a}}$ Fixed parameter; ${ }^{*} p<.05 ; X_{(50)}^{2}=52.05, p>.05 ; \mathrm{CFI}=0.99 ; \mathrm{IFI}=0.99 ; \mathrm{NNFI}=0.99 ; \mathrm{RMSEA}=0.02$.

\section{Discussion}

Structural contingency theory emphasized the importance ofthe environment in organizational structures, indicating that companies are configured in diverse ways in accordance with the external influences which they receive (Donaldson, 2001). The theory of organizational congruency or fit has provided the reference points needed to determine the conditions of structural fit (Drazin \& Van de Ven, 1985; Siggelkow (2002); Venkatraman \& Camillus, 1984). Using these two theoretical lenses, this study investigated the influence which organizational environment has on organizational results through structural co-alignment.

Several studies have already demonstrated the effect of organizational structure on performance; however, these effects differ between organizational variables (Courtright, Fairhurst, \& Rogers, 1989; Child, 1972; Dalton et al., 1980; Fegh-hi, 2010, Lee \& Yang, 2011; Lenz, 1980; Santra \& Giri, 2008; Pleshko \& Nickerson, 2008; Santra \& Giri; 2008), given the contingent nature of organizational design (Donaldson, 1987). In the case of SMEs in Bogotá, differentiation and centralization don't have any effect on results (H1, H2) when analyzed separately. Perhaps, due to their insular (isolated) state, a synergic effect that strengthens organizational effectiveness is not achieved. On the other hand, of the structural factors, which were analyzed, formalization did have a significant influence on performance (H3). As such, normalization produces the necessary standards to control organizational performance in the search for greater productivity (Carter, Hoffman, \& Cullen, 1994). Companies characterized by mechanical structures (Burns \& Stalker, 1961; McCaskey, 1974), as is the case for SMEs in Bogotá, try to reduce the discretional nature of work through the strict definition of processes, procedures, norms and functions in order to improve their efficiency (Mintzberg, 1979), as bureaucracy continues to be an model which favors performance (Weber, 1947).

In the framework of structural organization, the significant correlation between its three central variables (Hage, 1965; Hall, 1962; Hall, Haas \& Johnson, 1967; Hinings \& Lee; 1971; Pugh et al., 1968), confirms that they continue to be the principal imperatives to take into account in organizational design (Aiken, Bacharach, \& French, 1980; Dalton et al., 1980; Grinyer \& Yasai-Ardekani, 1980; Ranson, Minings \& Greenwood, 1980). The negative association of centralization with differentiation and formalization $(\mathrm{H} 4 \mathrm{a}, \mathrm{H} 4 \mathrm{~b})$, indicates that when directors concentrate on decision making, they shouldn't create new areas and positions of functional responsibility, and at the same time, the concentration of authority provides some degree of direct supervision thatmakes the formalization of behavior unnecessary; on the contrary, delegation of decision-making leads to increasing requirements for hierarchical and functional positions (differentiation) and a greater need to control the behavior of employees (formalization), a circumstance which confirms the initial findings of Hage (1965), Hage \& Aiken (1967) and Aiken et al. (1971).

Finally, SMEs in Bogotá confirm that structural co-alignment is a relevant strategic alternative to strengthen organizational performance. It is observed that greater functional division accompanied by control standards is favorable to strengthening performance $(\mathrm{H} 5 \mathrm{a}, \mathrm{H} 5 \mathrm{c})$, while the centralization of decision-making tends to reduce performance (H5b). Likewise, it is perceived that there is a highly significant influence on development when decisions regarding differentiation, centralization and formalization are taken jointly and simultaneously (H5d). This ratifies organizational congruence theories (Ensign, 2001; Fry \& Smith, 1987; Venkatraman \& Camillus, 1984; Venkatraman, 1989; Venkatraman, 1990), which establish that better organizational results are obtained when the company achieves a fit of structural factors to counteract exogenous forces that affect it. Therefore, this study found that industrial SMEs in Bogotá behave in accordance with this theory, as when differentiation, centralization and formalization are analyzed separately they have no influence on performance, but when they are co-aligned, they produce superior organizational results. 


\section{Conclusions and Implications}

Although, an important investigative spectrum exists regarding organizational structure and its effects on performance (Fegh-hi, 2010; Lee \& Yang, 2011; Lee \& Grover, 1999; Lenz, 1980; Menguc \& Auh, 2010), studies which integrate these different variables in a single construct under the framework of strategic co-alignment are still scarce, particularly in the case of Colombia and of SMEs, where there is still much work to be done particularly terms of investigations thatadequately reflect their currentsituation.

Structural contingency theory indicates that a single way of configuring organization structure does not exist, as organizational design depends on the influence of distinct contingent factors such as the environment and strategy (Donaldson, 2001). Given that partof this theory's work was left behind in the study of interactions between structuring variables, it is not clear how these relationships contribute to superior performance. For this reason, structural co-alignment theory provides a way of overcoming the gaps left by its predecessor and explains how to achievefit between structuring and environmental variables, as an essential condition to achieve greater organizational performance (Drazin \& Van de Ven, 1985; Venkatraman, 1989).

This study confirmed the basic assumption of organizational congruency theory that establishes the co-alignment of structural factors contributes to superior performance (Sillince, 2005; Veliyath \& Srinivasan, 1995; Venkatraman, 1990). In this case, when structural factors are jointly evaluated, an increased, positive and significant effect is observed on performance.

This study makes two important contributions. For strategic theory, it provides new empirical evidence thatconfirms the co-alignment of structural factors has a synergic capacity which influences organizational results to a greater extent than if these factors were evaluated separately. For strategic management, it provides elements to understand organizational functioning, as it indicates to managers that SMEs will strengthen their performance if they formalize behavior, create functional subunits and decentralize decision making in a joint or co-aligned way, verifying the synergic properties of organizational systems (Kast \& Rosenzweig, 1972).

\section{Limitations and Directions for Future Research}

This study was subject to some limitations, which deserve attention. Structural contingency theory establishes diverse situational factors that influence organizational structure as environment, strategy, technology, institutional power, and task uncertainty among others (Donaldson, 2001). Equally, it has been shown that environment presents diverse typologies such as uncertainty, dynamism, complexity, hostility and munificence being among the most important (Burton \& Obel, 2004; (Mintzberg, 1979). This study did not evaluate the influence of environment, and structural co-alignment could vary due to different environmental influences. Future studies could test the hypothesis of organizational congruence under different environmental assumptions and including other situational factorsas strategy and technology.

Although the hypothesis that differentiation and centralization influence performance when analyzed separately seems logical (Lee \& Yang, 2011; Santra \& Giri, 2008; Zheng et al., 2010), this study did not support thatassumption. Even though it was found that these variables don't produce the same effect when analyzed separately compared to when they are analyzed in conditions of co-alignment, it would be worth investigating in if alternative mediating effects exist in future research (Lee \& Grover, 1999; Liao et al., 2011).

Finally, the results obtained are based on a cross-sectional study applied to just one sample of SMEs in Bogotá's manufacturing sector. This segmentation could contribute to a particular characterization of the population, and the results would not be able to be extrapolated or generalized to all SMEs. Future investigations could conduct longitudinal studies with other types of SMEs in other regions, with the aim of establishing comparative parameters and reaching more wide-reaching conclusions.

\section{Acknowledgements}

The authors express their gratitude to the Universidad Autónoma de Colombiafor financing this investigation through university investigation system SUI in call for research No. 17of 2012, and would also like to thank Doctor Marcos Vera Leyton, research coordinator of FACEAC.

\section{References}

Aiken, M., \& Hage, J. (1971). The organic organization and innovation. Sociology, 5, 63-82.

Aiken, M., Bacharach, S. B., \& French, J. L. (1980). Organizational structure, work process, and proposal making in administrative bureaucracies. Academy of Management Journal, 23(4), 631-652. http://dx.doi.org/10.2307/255553

Anderson, J. C., \& Gerbing, D. W. (1988). Structural equation modeling in practice: A review and recommended 
two-step approach. $\quad$ Psychological Bulletin, $\quad$ 103(3), $411-423$. http://dx.doi.org/10.1037/0033-2909.103.3.411

Anderson, T., \& Warkov, S. (1961). Organizational size and functional complexity: a study of differentiation in hospitals. American Sociological Review, 26, 23-28.

Armstrong, J. S., \& Overton, T. S. (1977). Estimating nonresponse bias in mail surveys. Journal of Marketing Research, 14(3), 396-402.

Atuahene-Gima, K. (2005). Resolving the capability-rigidity paradox in new product innovation. Journal of Marketing, 69(4), 61-83. http://dx.doi.org/10.1509/jmkg.2005.69.4.61

Babbie, E. (2010). The practice of social research (12th ed.). Belmont, CA: Wadsworth Cengage.

Bagozzi, R., \& Yi, Y. (1988). On the evaluation of structural equation models. Journal of the Academy of Marketing Science, 16(1), 74-94. http://dx.doi.org/10.1007/BF02723327

Barney, J. (1991). Firm resources and sustained competitive advantage. Journal of Management, 17(1), 99-120.

Baruch, Y. (1999). Response rate in academic studies: A comparative analysis. Human Relations, 52(4), $421-438$.

Bentler, P. M. (2006). EQS 6 structural equations program manual. Encino, CA: Multivariate Software Inc.

Bentler, P. M., \& Weeks, D. (1980). Linear structural equations with latent variables. Psychometrika, 45(3), 289-308. http://dx.doi.org/10.1007/BF02293905

Blau, P. (1970). A formal theory of differentiation in organizations. American Sociological Review, 35(2), 201-218.

Burns, T., \& Stalker, G. (1961). The Management of Innovation. London: Tavistock.

Burton, R., \& Obel, B. (2004). Strategic organizational diagnosis and design: The dynamics offit. Massachusetts: Kluwer Academic Publishers.

Byrne, B. M. (2006). Structural equation modeling with EQS: Básic concepts, applications, and programming (2nd ed.). New Jersey: Lawrence Erlbaum Associates.

Carter, N., Hoffman, J., \& Cullen, J. (1994). The effects of computer technology and decision-making structure on organizational performance: a dual core model approach. Journal of High Technology Management Research, 5, 59-76.

Caruana, A., Morris, M. H., \& Vella, A. J. (1998). The effect of centralization and formalization on entrepreneurship in export firms. Journal of Small Business Management, 36(1), 16-29.

Cegarra-Navarro, J., Sánchez-Vidal, M. E., \& Cegarra-Leiva, D. (2011). Balancing exploration and exploitation of knowledge through an unlearning contextAn empirical investigation in SMEs. Management Decision, 49(7), 1099-1119.

Child, J. (1972). Organizational structure, environment and performance: the role of strategic choice. Sociology, $6(1), 1-22$.

Child, J. (1973). Strategies of control and organizational behavior. Administrative Science Quarterly, 18 , 1-17.

Chin, W. W. (1998). Issues and opinion on structural equation modeling. MIS Quarterly, 22(1), 1-10.

Clegg, S. (1981). Organization and control. Administrative Science Quarterly, 26, 545-562.

Courtright, J., Fairhurst, G., \& Rogers, E. (1989). Interaction patterns in organic and mechanistic systems. Academy of Management Journal, 32(4), 773-802.

Dalton, D. R., Todor, W. D., Spendolini, M. J., Fielding, G. J., \& Porter, L. W. (1980). Organization structure and performance: A critical review. Academy of Management Review, 5(1), 49-64. http://dx.doi.org/10.5465/AMR.1980.4288881

Damanpour, F., \& Gopalakrishnan, S. (1998). Theories of organizational structure and innovation adoption: The role of environmental change. Journal of Engineering and Technology Management, 15(1), 1-24. http://dx.doi.org/10.1016/S0923-4748(97)00029-5

Damanpour, F., \& Gopalakrishnan, S. (1999). Organizational adaptation and innovation: The dynamics of adopting innovation types. In K. Brockoff, A. Chakrabarti \& J. Hauschildt (Eds.), The dynamics of innovation: Strategic and managerial implications (pp. 57-80). Springer-Verlag.

Dewar, R., \& Werbel, J. (1979). Universalistic and contingency predictions of employee satisfaction and conflict. 
Administrative Science Quarterly, 24, 426-448.

Donaldson, L. (1987). Strategy and structural adjustment to regain fit and performance in defence of contingency theory. Journal of Management Studies, 24(1), 1-24.

Donaldson, L. (2001). The contingency theory of organizations. California: Sage Publications.

Drazin, R., \& Van de Ven, A. H. (1985). Alternative forms of fit in contingency theory. Administrative Science Quarterly, 30(4), 514-539.

Ensign, P. (2001). The concept of fit in organizational research. International Journal of Organization Theory \& Behavior (Marcel Dekker), 4(3), 287.

Fegh-hi, N. (2010). Strategic structure for organizational performance. International Journal of Management \& Innovation, 2(2), 9-23.

Fornell, C., \& Larcker, D. F. (1981). Evaluating structural equation models with unobservable variables and measurement error. Journal of Marketing Research, 18(1), 39-50.

Fredrickson, J. (1986). The strategic decision process and organizational structure. Academy of Management Review, 11(2), 280-297.

Fry, L. W., \& Smith, D. A. (1987). Congruence, contingency, and theory building. Academy of Management Review, 12(1), 117-132. http://dx.doi.org/10.5465/AMR.1987.4306496

Galbraith, J. R. (1973). Designing Complex Organizations. Reading, MA: Addison-Wesley.

Grant, R. M. (1991). The resource-based theory of competitive advantage: Implications for strategy formulation. California Management Review, 33(3), 114-135.

Grinyer, P. J., \& Yasai-Ardekani, M. (1980). Dimensions of organizational structure: a critical replication. Academy of Management Journal, 23, 405-421.

Hage, J., \& Aiken M. (1967). Relationship of centralization to other structural properties. Administrative Science Quarterly, 12, 72-92.

Hage, J. (1965). An axiomate theory of organizations. Administrative Science Quarterly, 10, 289-320.

Hair, J., Black, W., Babin, B., \& Anderson, R. (2009). Multivariate data analysis (7th ed.). New York: Prentice-Hall.

Hall, R. (1962). Intraorganizational structural variation: application of the bureaucratic model. Administrative Science Quarterly, 7, 295-308.

Hall, R., Haas, J., \& Johnson, N. (1967). Organizational size, complexity, and formalization. American Socilogical Review, 32, 903-922.

Hamel, G., \& Prahalad, C. (1990). The core competence of the corporation. Harvard Business Review, 68(3), 79-91.

Gs, C., \& Lee, G. (1971). Dimensions of organization structure and their context: a replication. Sociology, 5, 83-93.

Hooper, D., Coughlan, J., \& Mullen, M. R. (2008). Structural equation modelling: Guidelines for determining model fit. Electronic Journal of Business Research Methods, 6(1), 53-59.

Jöreskog, K. G. (1978). Structural analysis of covariance and correlation matrices. Psychometrika, 43(4), 443-477. http://dx.doi.org/10.1007/BF02293808

Kaplan, R. S., \& Norton, D. P. (1992). The Balanced Scorecard: measures that drive performance. Harvard Business Review, (January-February), 71-79.

Kast, F. E., \& Rosenzweig, J. E. (1972). General system theory: Applications for organization and management. Academy of Management Journal, 15(4), 447-465. http://dx.doi.org/0.2307/255141

Kilduff, M. (1993). Deconstructing organizations. The Academy of Management Review, 18(1), 13-31.

Kimberly, J. R., \& Rottman, D. B. (1987). Environment, organization and effectiveness: a biographical approach. Journal of Management Studies, 24, 595-622.

Lawrence, P., \& Lorsch, J. (1967). differentiation and integration in complex organizations. Administrative Science Quarterly, 12(1), 1-47.

Lee, C., \& Grover, V. (1999). Exploring mediation between environmental and structural attributes: The 
penetration of communication technologies in manufacturing organizations. Journal of Management Information Systems, 16(3), 187-217.

Lee, C., \& Yang, H. (2011). Organization structure, competition and performance measurement systems and their joint effects on performance. Management Accounting Research, 22(2), 84-104. http://dx.doi.org/10.1016/j.mar.2010.10.003

Lenz, R. T. (1980). Environment, strategy, organization structure and performance: Patterns in one industry. Strategic Management Journal, 1(3), 209-226.

Li, C., Chu, C., \& Lin, C. (2010). The contingent value of exploratory and exploitative learning for new product development performance. Industrial Marketing Management, 39(7), 1186-1197. http://dx.doi.org/10.1016/j.indmarman.2010.02.002

Liao, C., Chuang, S., \& To, P. (2011). How knowledge management mediates the relationship between environment and organizational structure. Journal of Business Research, 64(7), 728-736. http://dx.doi.org/10.1016/j.jbusres.2010.08.001

Malhotra, N. K. (1999). Marketing research: An applied orientation (3rd ed.). New Jersey: Prentice-Hall, Inc.

March, J. G., \& Sutton, R. I. (1997). Organizational performance as a dependent variable. Organization Science, $8(6), 698-706$.

Marín-Idárraga, D. A. (2012). Organizational structure and its design parameters: descriptive analysis in industrial Bogotá SMEs. Estudios Gerenciales, 28(123), 43-64.

Martínez-López, F. J., Gázquez-Abad, J. C., \& Sousa, C. M. P. (2013). Structural equation modelling in marketing and business research:Critical issues and practical recommendations. European Journal of Marketing, 47(1), 115-152. http://dx.doi.org/10.1108/03090561311285484

McCaskey, M. (1974). An introduction to organizational design. California Management Review, 17(2), 13-20.

Meijaard J, Brand, M. J., \& Mosselman, M. (2005). Organizational structure and performance in Dutch small firms. Small Business Economics, 25, 83-96.

Menguc, B., \& Auh, S. (2010). Development and return on execution of product innovation capabilities: The role of organizational structure. Industrial Marketing Management, 39(5), 820-831. http://dx.doi.org/10.1016/j.indmarman.2009.08.004

Mintzberg, H. (1979). The structuring of organizations: A synthesis of the research. Englewood Cliffs, NY: Prentice-Hall.

Nadler, D. A., \& Tushman, M. L. (1999). The organization of the future: Strategic imperatives and core competencies for the 21st century. Organizational Dynamics, 28(1), 45-60.

Neely, A., Gregory, M., \& Platts, K. (1995). Performance measurement system design: A literature review and research agenda. International Journal of Operations \& Production Management, 15(4), 80-116. http://dx.doi.org/10.1108/01443579510083622

Nudurupati, S. S., Bititci, U. S., Kumar, V., \& Chan, F. T. (2011). State of the art literature review on performance

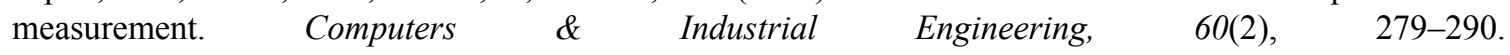
http://dx.doi.org/10.1016/j.cie.2010.11.010

Nunnally, J. C. (1978). Psychometric theory. New York: McGraw-Hill.

Pleshko, L., \& Nickerson, I. (2008). Strategic orientation, organizational structure, and the associated effects on performance in industrial firms. Academy of Strategic Management Journal, 7(1), 95-110.

Porter, M. E. (1990). The Competitive Advantage of Nations. New York: Free Press, MacMillan.

Pugh, D. S., Hickson, D. J., Hinnings, C. R., \& Turner, C. (1968). Dimensions of organizational structure. Administrative Science Quarterly, 13, 65-105.

Rodríguez, A. G. (2003). La realidad de la Pyme colombiana: Desafio para el desarrollo. Bogotá: FUNDES.

Rumelt, R. P., Schendel, D., \& Teece, D. (1991). Strategic management and economics. Strategic Management Journal, 12, 5-29.

Santra, T., \& Giri, V. N. (2008). Effect of organizational structure on organizational effectiveness through face-to-face communication. ICFAI Journal of Organizational Behavior, 7(2), 28-38.

Sarkees, M., Hulland, J., \& Prescott, J. (2010). Ambidextrous organizations and firm performance: The role of 
marketing function implementation. Journal of Strategic Marketing, 18(2), 165-184. http://dx.doi.org/10.1080/09652540903536982

Schoonhoven, C. B. (1981). Problems with contingency theory: Testing assumptions hidden within the language of contingency theory. Administrative Science Ouarterly, 26, 349-377,

Siggelkow, N. (2002). Evolution toward fit. Administrative Science Quarterly, 47, 125-129.

Sillince, J. A. (2005). A contingency theory of rhetorical congruence. Academy of Management Review, 30(3), 608-621. http://dx.doi.org/10.5465/AMR.2005.17293722

Slater, S. F., \& Olson, E. M. (2000). Strategy type and performance: the influence of sales force management. Strategic Management Journal, 21, 813-830.

Tidd, J. (2000). From Knowledge Management to Strategic Competence: Measuring technological, market and organizational innovation. Chicago: Imperial College Press.

Veliyath, R., \& Srinivasan, T. C. (1995). Gestalt approaches to assessing strategic coalignment: a conceptual integration. British Journal of Management, 6(3), 205-219.

Venkatraman, N. (1989). The concept of fit in strategy research: Toward verbal and statistical correspondence. Academy of Management Review, 14(3), 423-444. http://dx.doi.org/10.5465/AMR.1989.4279078

Venkatraman, N. (1990). Performance implications of strategic coalignment: A methodological perspective. Journal of Management Studies, 27(1), 19-41.

Venkatraman, N., \& Camillus, J. C. (1984). Exploring the concept of "fit" in strategic management. Academy of Management Review, 9(3), 513-525. http://dx.doi.org/10.5465/AMR.1984.4279696

Venkatraman, N., \& Ramanujam, V. (1986). Measurement of business performance in strategy research: A comparison of approaches. Academy of Management Review, 11(4), 801-814. http://dx.doi.org/10.5465/AMR.1986.4283976

Weber, M. (1947). The theory of social and economic organization. NewYork: Free Press.

Wernerfelt, B. (1984). A resource-based view of the firm. Strategic Management Journal, 5(2), 171-180.

Williamson, O. (1970). Corporate control and business behavior. Englewoods Cliffs: Prentice Hall.

Zhang, D., Linderman, K., \& Schroeder, R. G. (2012). The moderating role of contextual factors on quality management practices. Journal of Operations Management, 30(1), 12-23.

Zheng, W., Yang, B., \& McLean, G. N. (2010). Linking organizational culture, structure, strategy, and organizational effectiveness: Mediating role of knowledge management. Journal of Business Research, 63(7), 763-771. http://dx.doi.org/10.1016/j.jbusres.2009.06.005

\section{Notes}

Note 1. According to Williamson (1970), the M-form corresponds to the type of multi-divisional structure proposed by Alfred Chandler, which consists of internal organizational expansion in order to improve efficiency through a process of inverse integration.

Note 2. To avoid squaring all of the correlations, the square root of $A V E$ is usually obtained as an equivalent value (Cegarra-Navarro, Sánchez-Vidal \& Cegarra-Leiva, 2011).

\section{Copyrights}

Copyright for this article is retained by the author(s), with first publication rights granted to the journal.

This is an open-access article distributed under the terms and conditions of the Creative Commons Attribution license (http://creativecommons.org/licenses/by/3.0/). 